\title{
Direct Intraoperative Reduction of Basilar Invagination Associated with Atlantoaxial Subluxation - Technical Note
}

\section{Redução intraoperatória direta da invaginação basilar associada a subluxação atlantoaxial - nota técnica}

\author{
Victor Emmanuel Passos Barretto ${ }^{1,3}$ Camila Andrade de Sousa ${ }^{2}$ Anderson Loureiro ${ }^{3}$ Diogo Arruda ${ }^{3}$ \\ Anderson Matos $^{3}$ Andrei Fernandes Joaquim ${ }^{3,4}$ \\ ${ }^{1}$ Hospital Dr. Mario Gatti, Campinas, São Paulo, Brazil \\ 2 Department of Neurosurgery, Hospital Santa Casa de Limeira, \\ Limeira, São Paulo, Brazil \\ ${ }^{3}$ Department of Neurosurgery, Hospital Municipal Dr. Mário Gatti, \\ Campinas, São Paulo, Brazil \\ ${ }^{4}$ Department of Neurosurgery, Universidade Estadual de Campinas \\ (Unicamp), Campinas, São Paulo, Brazil

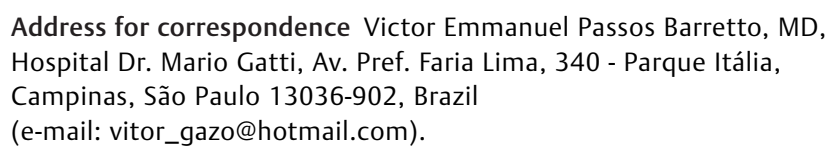
Hospital Dr. Mario Gatti, Av. Pref. Faria Lima, 340 - Parque Itália, Campinas, São Paulo 13036-902, Brazil (e-mail: vitor_gazo@hotmail.com). \\ Arq Bras Neurocir 2017;36:260-263.
}

\begin{abstract}
In the present article, we describe a technique of direct intraoperative reduction of congenital atlantoaxial subluxation associated with severe basilar invagination and Keywords

- basilar invagination

- atlantoaxial subluxation

- technical note

- intraoperative reduction atlas assimilation. It consists of a wide dissection of the craniovertebral junction, exposing the region between the superior facet of $C 2$ and the occiput (described as a "pseudoarticulation" by some authors). After exposure, a self-rotating small dissector or Kobe is used bilaterally, pushing C2 anteriorly and inferiorly, with reduction of the dislocation, followed by craniovertebral fixation. The technique is safe and eliminates the need for an anterior approach to the odontoid reduction, as well as the need to dissect the $\mathrm{C} 1-2$ joint.

\section{Resumo}

Palavras-chave

- invaginação basilar

- subluxação atlantoaxial

- nota técnica

- redução intraoperatória

Neste artigo, descrevemos a técnica de redução intraoperatória direta de subluxação atlantoaxial congênita associada a invaginação basilar grave e assimilação do atlas. Ela consiste em ampla dissecção da junção craniovertebral, expondo a região entre a face superior da C2 e o osso occipital (descrita como uma "pseudoarticulação" por alguns autores). Após exposição, um descolador pequeno ou Kobe é usado bilateralmente com rotação própria, deslocando C2 anterior e inferiormente, com redução da luxação, seguido de fixação craniovertebral. A técnica é segura e elimina a necessidade de uma abordagem anterior para a ressecção do odontoide, além de evitar a dissecação da junta C1-C2.
\end{abstract}

received

August 2, 2017

accepted

October 17, 2017

published online

December 6, 2017
DOI https://doi.org/

10.1055/s-0037-1608882. ISSN 0103-5355.
Copyright $\odot 2017$ by Thieme Revinter

Publicações Ltda, Rio de Janeiro, Brazil
License terms

(c) $(1) \$$ 


\section{Introduction}

Basilar invagination (BI) is a primary developmental anomaly in which the spine is elevated and protruding relative to the base of the skull. ${ }^{1}$ It is one of the most common congenital craniocervical malformations. ${ }^{2-6}$ It is defined when the apex of the odontoid process is at least $2.5 \mathrm{~mm}$ above the Chamberlain, although other thresholds were proposed, such as $5 \mathrm{~mm} .^{2-7}$

When symptomatic, BI may present with many clinical syndromes, isolated or combined, such as: cervical pain, cranial nerve syndromes, superficial and deep sensory syndromes, cerebellar symptoms, intracranial syndrome and hydrocephalus, bulbar symptoms, vertebrobasilar insufficiency, among others. ${ }^{8-12}$

The first publication on the surgical treatment of BI was made by Ebenius ${ }^{13}$ in 1934. Throughout the years, occipitocervical fixation techniques with external orthoses were initially proposed, followed by the use of autologous bone grafts (such as the fibular strut), and cables and wires for fixation and fusion $^{2-6}$. More recently, screws, rods and plates have been employed with immediate stabilization and high fusion rates. $^{14-21}$ However, until recently, anterior craniocervical compression required combined approaches, with anterior odontoidectomy due to anterior brainstem compression.

$\mathrm{Goel}^{22}$ revolutionized the treatment of BI with associated atlantoaxial dislocation ${ }^{2-6}$ using C1-2 fixation with an intraarticular spacer, when both anterior and posterior compressions were solved with craniocervical junction realigment. ${ }^{22}$

In the present article, we present a direct intraoperative craniocervical realignment technique, with reduction of the anterior compression without the need of placing intraarticular cages and without preoperative cranial traction, as an alternative to treat this challenging malformation.

\section{Case and Technical Description}

We report the case of a 41-year-old male patient, with no comorbidities, who complained of decreasing muscle strength in his four limbs, cervical pain and paresthesia in the upper limbs, which had progressed over the previous 4 years. The patient had no speech difficulties or swallowing disorders. He was able to walk without assistance, but with some difficulty.

A computed tomography (CT) scan revealed a clear BI with atlantoaxial dislocation. C1 was assimilated with the occipital condyles. The tip of the odontoid was $17.3 \mathrm{~mm}$ above the Chamberlain line. In addition, the patient had atlas assimilation (fused to the occipital condyles). Atlantoaxial subluxation was clearly evident. A magnetic resonance imaging (MRI) scan showed anterior brainstem compression by the tip of the odontoid, as well as C3-4 compression (-Fig. 1).

With the patient in prone position and with rigid fixation of the skull, with a neutral craniocervical alignment, the occipitocervical region was exposed, as well as the subaxial cervical spine. An occipital plate was fixed with screws at the occipital squama, as well as C2 laminar screws, C3 and C4 lateral masses screws. Decompression of the foramen magnum was performed to avoid further compression of the neural tissue during the realignment procedure; a C3-4 laminectomy was also performed. A Cobb instrument inserted between the "pseudojoint" formed between the superior pars of $\mathrm{C} 2$ and the occipital squama was rotated, pushing the axis anteriorly and inferiorly, reducing the subluxation and descending the tip of the odontoid (as shown in - Fig. 2).

After reduction, in the new space formed between the axis and the occiput, a tricortical iliac graft was placed, and the occipitocervical stem was fixed, maintaining the reduction.

In -Figs. 3 and $\mathbf{4}$ we present the radiological result. The clivus canal angle increased from $105.6^{\circ}$ preoperatively to $123.1^{\circ}$ after surgery. The tip of the dens above the Chamberlain line descended significantly. The patient was discharged at postoperative day 3 with tremendous improvement in his symptoms.

\section{Discussion}

The treatment of patients with congenital craniocervical junction malformation consists mainly of restoring the craniocervical alignment, fixing the instabilities when present, and decompressing the neural structures. ${ }^{2-6}$ Recently, modern

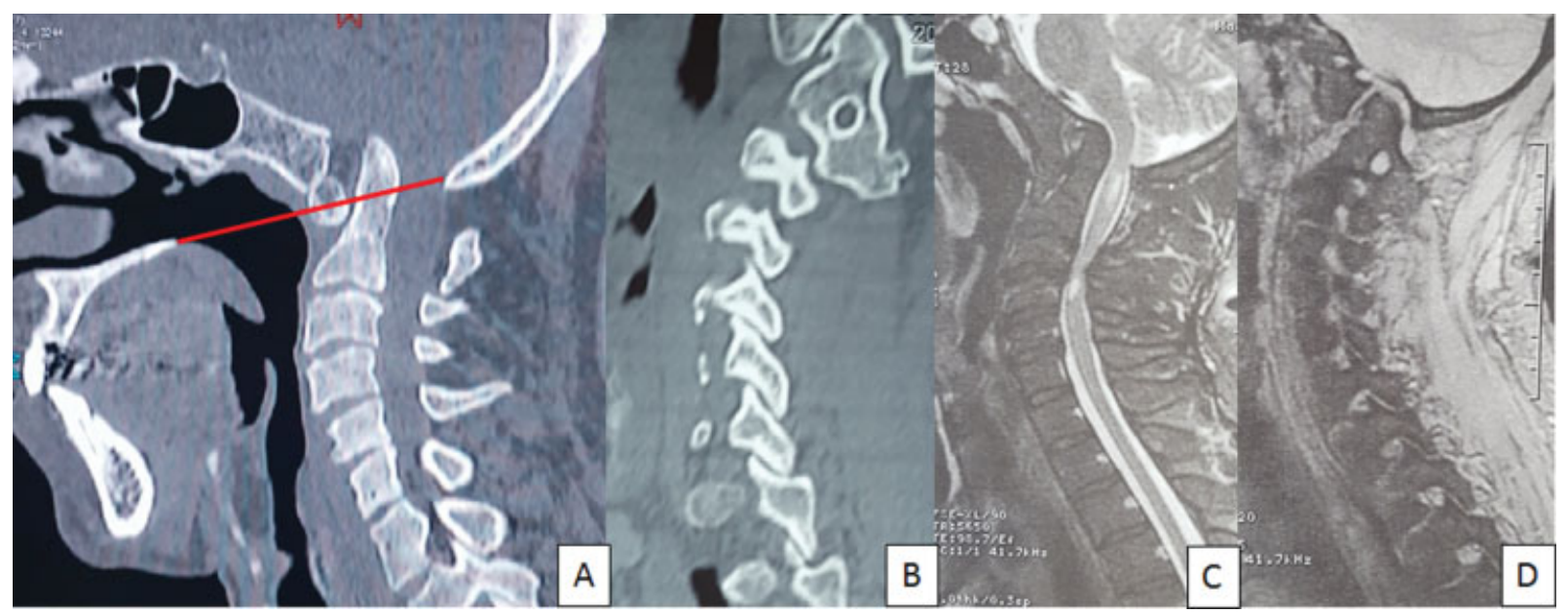

Fig. 1 (A) Sagittal CT scan showing the tip of the dens above the Chamberlain line (17.3 mm). (B) Sagittal CT scan with C1-2 facet joint subluxation. (C) Sagittal MRI showing anterior brainstem compression caused by the tip of the odontoid, as well as C3-4 cervical compression. (D) Sagittal MRI showing atlas assimilation and the C1-2 facet joint subluxation. 


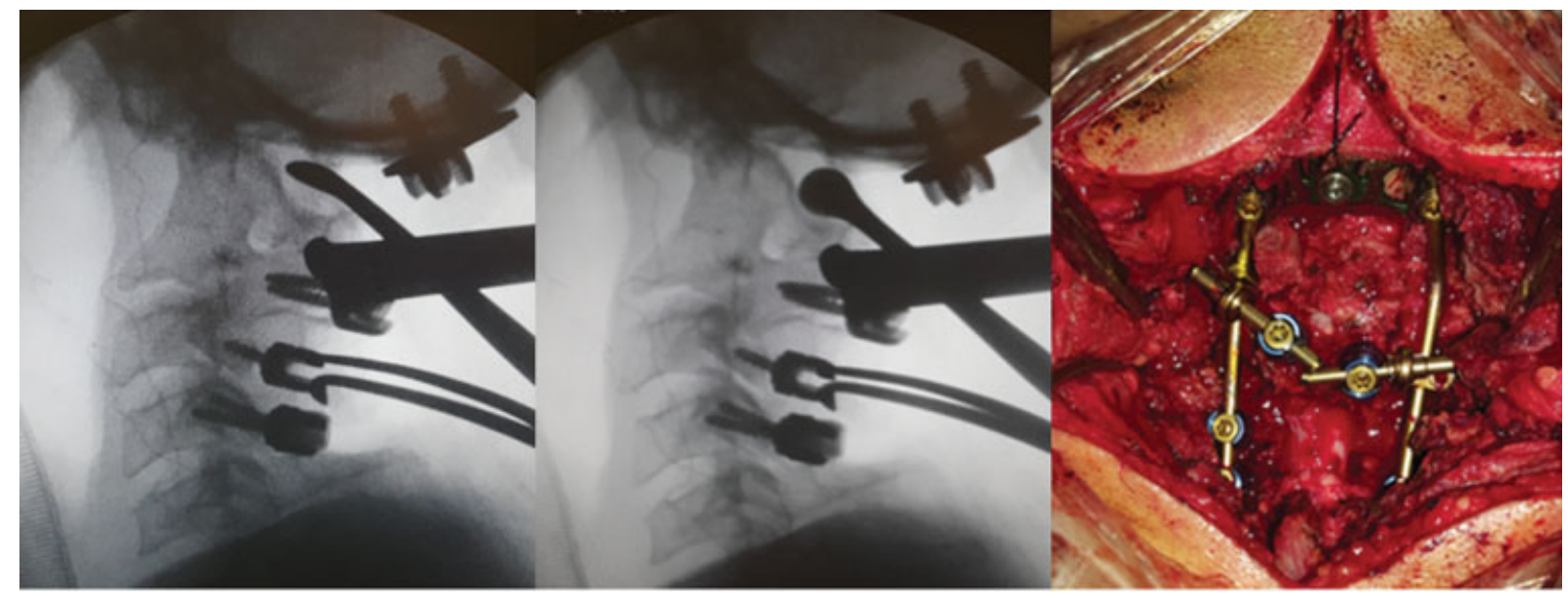

Fig. 2 (A) The Cobb instrument was inserted between the superior pars of C2 and the occipital squama. (B) We rotated the Cobb, dislocating C2 anteriorly and inferiorly. After that, we inserted in this new space a tricortical iliac crest graft and fixed the rods. (C) Intraoperative view of the construction.

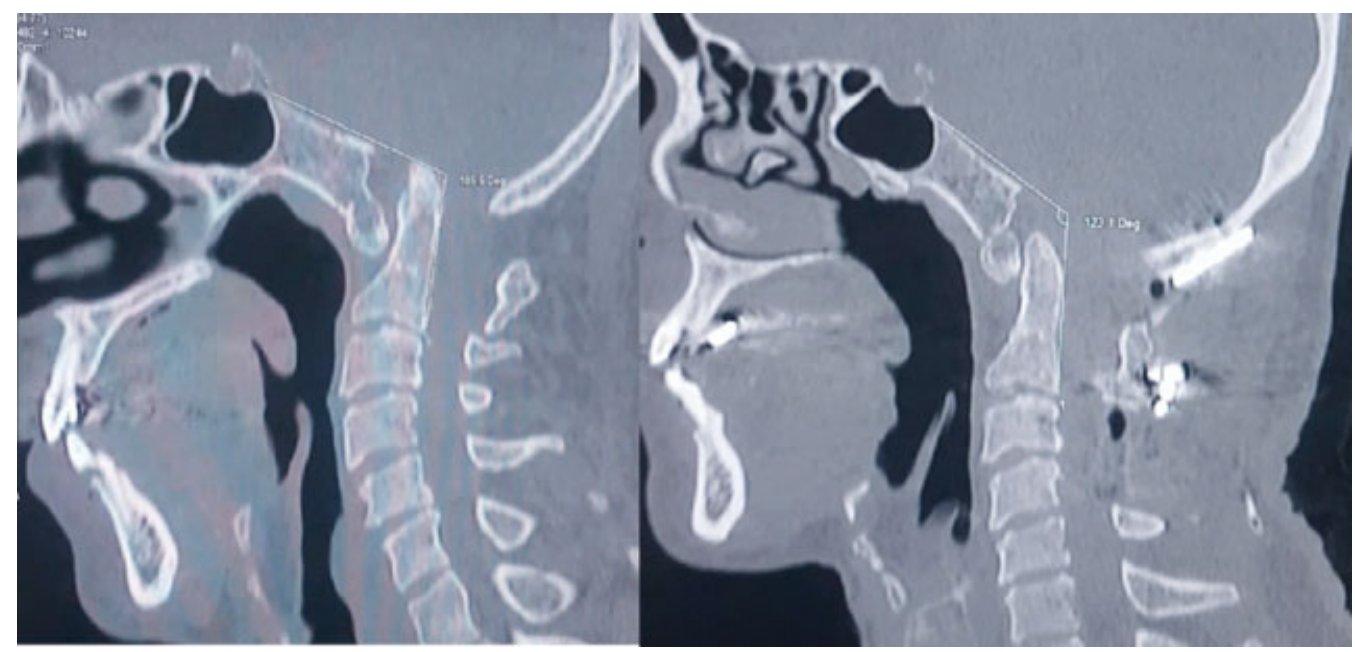

Fig. 3 Sagittal CT scan - preoperative (A), the clivus canal angel was $105.3^{\circ}$ versus $123.1^{\circ}$, seen at (B).

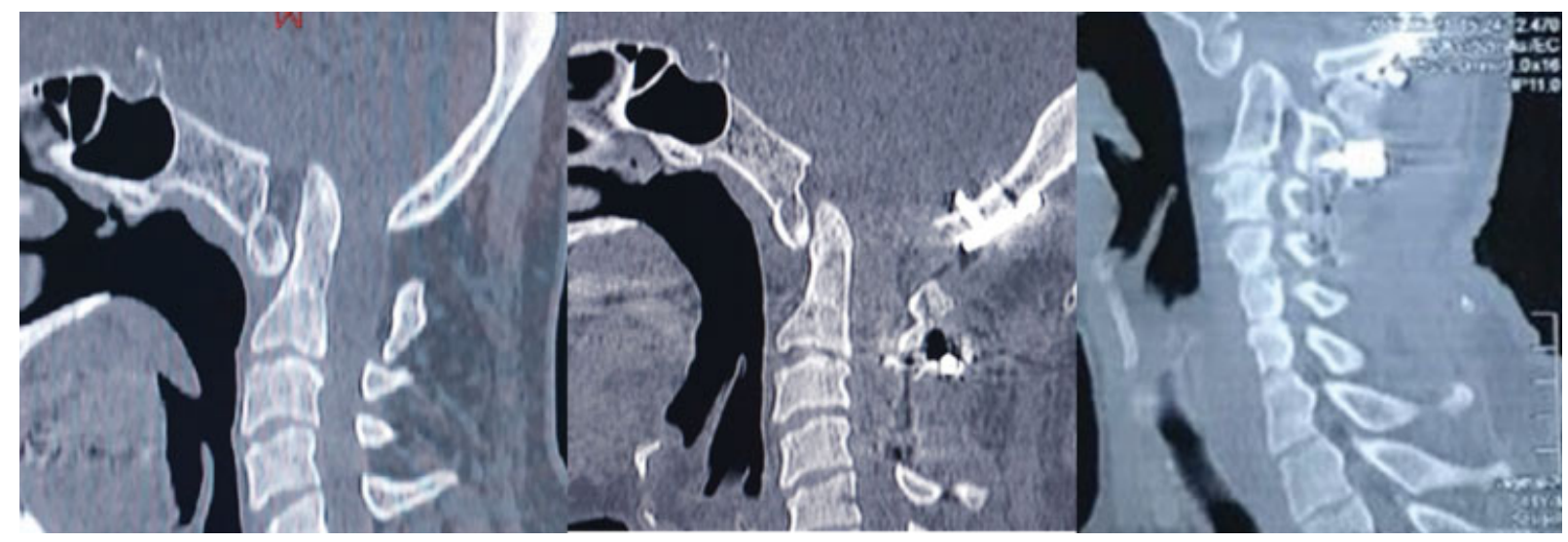

Fig. 4 Sagittal CT scan - preoperatively (A); (B) postoperatively with the dens displaced downward and the posterior fossa decompression; (C) sagittal CT scan with the tricortical bone inserted between the space created between C2 and the occipital squama (arrow). 
techniques of occipitocervical fixation enabled the treatment of these challenging diseases with an exclusive posterior approach, eliminating the need of an anterior approach (such as the transoral or endonasal endoscopies for resection of the odontoid). ${ }^{23-26}$

In the presence of atlantoaxial instability, realignment can be achieved with preoperative cranial traction, in which a prolonged decubitus is necessary, and there are risks of immobilization to the patient, as well as tremendous disconfort. ${ }^{2-6}$ Distraction of the C1-C2 joints with the placement of intraarticular spacers, which enables the realignment and eliminates the need of anterior surgery, is advocated, but it requires tremendous surgical skills and management of the vertebral artery, which usually has anomalies in these patients. ${ }^{27}$ Other posterior techniques of craniocervical realignment, such as the one proposed by Chandra et al, ${ }^{28}$ which consists of- distraction, compression, extension and reduction (DCER), are also effective, but they require a greater learning curve.

In this setting, our proposed technical note provides a relative safe and easy way to restore craniocervical realignment in BI associated with atlantoaxial subluxation. This maneuver may be incorporated into the arsenal of surgeons who handle these complex malformations.

\section{Conflicts of interest}

The authors have no conflicts of interest to disclose.

\section{References}

1 Kim FM. Developmental anomalies of the craniocervical junction and cervical spine. Magn Reson Imaging Clin N Am 2000;8(03):651-674

2 Joaquim AF. Management of Basilar Invagination. J Bras Neurocirurg 2013;24(01):53-59

3 Joaquim AF, Ghizoni E, Almeida JPC, Anderle DV, Tedeschi H. Basilar Invagination Secondary to Hypoplasia of the Clivus - Is there Indication for Craniocervical Fixation? Coluna/Columna 2014;13(01):69-70

4 Joaquim AF, Ghizoni E, Giacomini LA, Tedeschi H, Patel AA. Basilar invagination: Surgical results. J Craniovertebr Junction Spine 2014;5(02):78-84

5 Joaquim AF, Fernandes YB, Mathias RN, et al. Incidence of basilar invagination in patients with tonsillar herniation? A case control craniometrical study. Arq Neuropsiquiatr 2014;72(09):706-711

6 Joaquim AF. Letter to the editor: treatment of craniocervical instability using a posterior-only approach. J Neurosurg Spine 2015;22(03):334-335

7 Chamberlain WE. Basilar Impression (Platybasia): A Bizarre Developmental Anomaly of the Occipital Bone and Upper Cervical Spine with Striking and Misleading Neurologic Manifestations. Yale J Biol Med 1939;11(05):487-496

8 Ackermann JF. Ueber die Kretinen, einebesondere Menschenabart in den Alpen. Gotha, in der EttingerschenBuchhandlung, 1790

9 Ackermann R, Wolff H. Neurologische Stoerungenbei Missbildungenam Schaedel-Halsuebergang (Basale Impression). Dt Z NervHeilk 1953;170:47-61

10 Brocher JEW. Die Occipito-Cervical-Gegend: einediagnostishpathogenetisheStudie. Stuttgarf.GeorgThiemeVerlag, 1955
11 Klaus E. Die basilaere Impression. Leipzig: S Hirzel; 1969

12 List CF. Neurologic syndromes accompanying developmental anomalies of occipital bone, atlas and axis. Arch Neurol Psychiatry 1941;45(04):577-616

13 Ebenius B. The roentgen appearance in four cases of basilar impression. Acta Radiol 1934;15(06):652-656

14 Pait TG, Al-Mefty O, Boop FA, Arnautovic KI, Rahman S, Ceola W. Inside-outside technique for posterior occipitocervical spine instrumentation and stabilization: preliminary results. J Neurosurg 1999;90(1, Suppl)1-7

15 Pierce DS, Barr JS Jr. Fractures and dislocations at the base of the skull and upper cervical spine. In Cervical Spine Research Society. The cervical spine. 2.Ed. Philadelphia: JB Lippincot; 1989:312-324

16 Habal MB. Different forms of bone grafts. In Habal MB, Reddi AH (eds). Bone grafts and bone substitutes. Philadelphia: Saunders; 1992:6-8

17 Dickman CA. Biology of the spine fusion. In Dickman CA, Spetzler RF, Sonntag VKH (eds). Surgery of the craniovertebral junction. New York: Thieme; 1998:685-698

18 Murphy M, Southwich WO. Posterior approaches and fusions. In Cervical Spine Research Society. The cervical spine. 2.Ed. Philadelphia: JB Lippincot; 1989:775-791

19 Crockard HA, Pozo JL, Ransford AO, Stevens JM, Kendall BE, Essigman WK. Transoral decompression and posterior fusion for rheumatoid atlanto-axial subluxation. J Bone Joint Surg Br 1986;68(03):350-356

20 Roy-Camille R, Saillant G, Mazel C. Internal fixation of the unstable cervical spine by a posterior osteosynthesis with plates and screws. In Cervical Spine Research Society. The cervical spine. 2.Ed. Philadelphia: JB Lippincott; 1989:390-403

21 MacKenzie AI, Uttley D, Marsh HT, Bell BA. Craniocervical stabilization using Luque/Hartshill rectangles. Neurosurgery 1990;26 (01):32-36

22 Goel A. Basilar invagination, Chiari malformation, syringomyelia: a review. Neurol India 2009;57(03):235-246

23 Jian FZ, Chen Z, Wrede KH, Samii M, Ling F. Direct posterior reduction and fixation for the treatment of basilar invagination with atlantoaxial dislocation. Neurosurgery 2010;66(04):678-687, discussion 687

24 Menezes AH. Craniovertebral junction abnormalities with hindbrain herniation and syringomyelia: regression of syringomyelia after removal of ventral craniovertebral junction compression. J Neurosurg 2012;116(02):301-309

25 Salunke P, Behari S, Kirankumar MV, Sharma MS, Jaiswal AK, Jain VK. Pediatric congenital atlantoaxial dislocation: differences between the irreducible and reducible varieties. J Neurosurg 2006; 104(2, Suppl)115-122

26 Bollo RJ, Riva-Cambrin J, Brockmeyer MM, Brockmeyer DL. Complex Chiari malformations in children: an analysis of preoperative risk factors for occipitocervical fusion. J Neurosurg Pediatr 2012; 10(02):134-141

27 Goel A. Treatment of basilar invagination by atlantoaxial joint distraction and direct lateral mass fixation. J Neurosurg Spine 2004;1(03):281-286

28 Chandra PS, Prabhu M, Goyal N, Garg A, Chauhan A, Sharma BS. Distraction, Compression, Extension, and Reduction Combined With Joint Remodeling and Extra-articular Distraction: Description of 2 New Modifications for Its Application in Basilar Invagination and Atlantoaxial Dislocation: Prospective Study in 79 Cases. Neurosurgery 2015;77(01):67-80, discussion 80 10.1227/NEU.0000000000000737 